\title{
PENGATURAN IZIN PEMBUANGAN LIMBAH PABRIK KE LAUT DI KABUPATEN JEMBRANA
}

\author{
I Putu Endra Wijaya Negara, Program Studi Magister Ilmu Hukum, Fakultas \\ Hukum Universitas Udayana, E-mail: putuendrawi05@gmail.com \\ Putu Edgar Tanaya, Fakultas Hukum Universitas Udayana, \\ E-mail: putuendrawi05@gmail.com \\ doi: https://doi.org/10.24843/KS.2020.v08.i08.p13
}

\begin{abstract}
Abstrak
Berupaya untuk mengkaji serta mengetahui pengaturan terkait pembuangan limbah pabrik ke laut sebelum adanya izin yang diterbitkan oleh Pemerintah Daerah serta mengetahui dalam tindakan pengawasan pemerintah Kabupaten Jembrana terhadap Pabrik yang membuang limbah ke laut sebelum adanya izin dari Pemerintah Daerah. Penelitian ini mengaplikasikan penelitian hukum normatif. Izin tidak berkenan melaksanakan entitas melainkan diizinkan. Maka, kegiatan kepada suatu sasaran tertentu dalam latar belakangnya tidak diperbolehkan. Seseorang maupun organ aturan - aturan bisa melaksanakan usaha maupun aktivitas atas suatu objek tersebut bila memperoleh izin dari pemerintah/pemerintah daerah yang menumbuhkan fungsinya kepada aktivitas yang dilaksanakan oleh orang atau golongan yang berhubungan. Peranan pemantauan terkait halnya kepada izin yang sudah dimunculkan secara absolut dibutuhkan bertujuan menghindari kekeliruan - kekeliruan terkait dengan izin yang sudah dimunculkan sehingga tidak disalahgunakan. Pemantauan terkait dengan izin tersebut merupakan tanggungjawab instansi - instansi yang mengeluarkan izin tersebut.
\end{abstract}

Kata Kunci : Pengaturan, Izin, Pembuangan Limbah

\begin{abstract}
To knows related to study the the plant waste into the sea before the permits issued by a government local and not in the act of the supervision of a government jembrana regency to plant of waste into the sea before the permission from local government. This study as law normative research. Permission had given implement entity but allowed. So, activities to a a specific target in a backdrop not allowed. Someone and organs - which start to do the business activity upon an object and the government when obtaining licenses / local governments who them to activity conducted by the party that deals. Related complaint to the role of monitoring without have raised in absolute terms to avoid needed a without a relating to have raised so is not misused. Monitoring relating to permit responsibility - agencies is agency issued the permit.
\end{abstract}

Keywords : Regulation, License, Waste Disposal 


\section{Pendahuluan}

\subsection{Latar Belakang}

Permasalahan lingkungan hidup bermula disebabkan oleh beragam hal, yakni salah satunya pertambahan penduduk. Lingkungan hidup dalam dimensi teoritis dilihat secara konstituen yang absolute pada aktivitas masyarakat, tidak luput pada aktivitas seseorang yang bersangkutan. ${ }^{1}$ Pertambahan masyarakat yang bertambah banyak menyebabkan aktifitas ekonomi pula bertumbuh dengan pesat. Aktivitas ekonomi atau pengembangan pada saat ini mulai bertambah pesat sehingga dapat mengakibatkan terkontaminasinya serta dapat menyebabkan destruksi kepada lingkungan hidup sehingga dengan demikian bentuk serta peran landasan ekosistem yang merupakan penunjang kehidupan akan berdampak buruk. Salah satu sarana yang faktual dalam pengelolaan lingkungan hidup adalah izin. Inzin secara Universal (perizinan) merupakan suatu kesepakatan pada pemegang kuasa yang kaitannya dalam Undang-Undang maupun kebijakan kedaulatan, bertujuan ketika kondisi tersebut berkepanjangan pada ketetapan - ketetapan pembatasan dalam peraturan. Arti kaidah - kaidah yang bisa dilihat pada perizinan yakni adanya persetujuan yang bertujuan melaksanakan entitas yang seharusnya dicegah, maka hendak bisa dilihat pada beragam bentuk perizinan, diantaranya yakni izin, dispensasi, lisensi, konsesi, rekomendasi, dan lain-lain.

Izin merupakan bentuk ketentuan kedaulatan pada hukum Administrasi Negara. Selaku ketentuan kedaulatan, bahwa izin adalah perbuatan hukum kedaulatan bersumber pada kekuatan umum yang mengizinkan maupun menyetujui berdasarkan hukum oleh masyarakat maupun susunan organ hukum yang bertujuan melaksanakan objek aktivitas. Pada halnya melakukan suatu perizinan tersebut sepertinya masyarakat serta pelaku usaha sesungguhnya tidak amat peduli terhadap izin yang patut dilaksanakan tersebut. ${ }^{2}$

Berdasarkan Peraturan Pemerintah No. 27 Tahun 2012 tentang Pengelolaan Izin Lingkungan Hidup dijelaskan dalam hal ini kaitannya terhadap orientasi pembentukkan yang berkepanjangan Indonesia merupakan pembentukkan ekonomi kepada bertumpukkan dalam pembentukkan industri antara lain memanfaatkan beragam parietas objek kimia dan elemen radioaktif. Selain menciptakan barang yang konstruktif kepada penduduk atau warga, industrialisasi pula menyebabkan suatu pandangan, diantaranya diperolehkannya limbah yang apabila dibuang ke lingkungan seperti artikel jurnal yang penulis angkat akan berdampak mengintimidasi lingkungan hidup tersebut beserta kelangsungan hidup masyarakat, dan juga biota yang hidup didalam laut.

\footnotetext{
${ }^{1}$ Siahaan N.H.T, Siahaan. Hukum Lingkungan ( Jakarta, Pancuran Alam, 2009 ), h. 2.
}

2 Panata, Y. "Penurunan Status Kawasan Cagar Alam Menjadi Taman Wisata Alam Di Kabupaten Garut Dihubungkan Dengan Undang-Undang No 5 Tahun 1990 Tentang Konservasi Sumber Daya Alam Hayati Dan Ekosistemnya Jo Undang-Undang No 32 Tahun 2009 Tentang Perlindungan Dan Pengelolaan Lingkungan Hidup". (, Fakultas Hukum Universitas Pasundan, Doctoral dissertation, 2019). 
Menurut Undang - Undang No. 32 Tahun 2009 tentang Perlindungan dan Pengelolaan Lingkungan Hidup (PPLH), yakni ditemukan ada 2 (dua) jenis izin, diantaranya pertama, izin lingkungan merupakan izin yang diserahkan terhadap setiap orang yang melaksanakan usaha dan/atau kegiatan yang wajib amdal maupun UKL-UPL terkait rancangan perlindungan dan pengelolaan lingkungan hidup semacam ketentuan untuk mendapatkan izin usaha dan/atau kegiatan. ${ }^{3}$ Kedua, Izin usaha dan/atau kegiatan merupakan izin yang dilahirkan oleh institusi teknis yang bertujuan melaksanakan usaha dan/atau kegiatan. Berdasarkan Pasal 1 angka 35 dan 36 UU. No 32 tahun 2009 tentang PPLH terkait izin lingkungan adalah peraturan prasyarat untuk mendapatkan izin usaha dan/atau kegiatan. Untuk mendapatkan izin yang terbilang maka orang serta badan hukum harus membereskan dan memperoleh izin lingkungan terlebih dahulu. Selama itu izin lingkungan tersebut didapatkan sesudah terpenuhinya prasyarat dan menjalani ketentuan - ketentuan administrasi. Kedudukan Pemerintah berdasarkan urusan tersebut yakni merancang peraturan berbentuk izin lingkungan, yakni salah satunya pemberian izin lingkungan menyinggung tentang pembuangan limbah cair. Dewasa ini terdapat sangat banyak pabrik maupun usaha - usaha yang membuang limbah sisa dari hasil produksinya dengan sembarangan dan tidak sesuai dengan prosedur atau peraturan, salah satunya pabrik tepung ikan yakni membuang limbahnya begitu saja ke laut sebelum ada izin. Dalam pengolahan limbah tersebut Dinas Lingkungan Hidup (DLH) Kabupaten Jembrana menyampaikan bahwa memang diperbolehkan limbah tersebut dibuang ke laut, hanya saja harus ada izin yang wajib dikeluarkan oleh pemerintah pusat.

Berdasarkan Pasal 18 ayat (1) Undang - Undang No. 32 Tahun 2009 Tentang Pelindungan dan Pengelolaan Lingkungan Hidup dijelaskan bahwa :

"Setiap usaha dan/atau kegiatan yang menimbulkan dampak kepada lingkungan hidup harus mempunyai analisis terhadap pengaruh lingkungan hidup untuk mendapatkan izin melaksanakan usaha dan/atau kegiatan".

Merujuk pada Pasal tersebut mampu dipaparkan maka izin yang dimaksudkan adalah Izin Pembuangan Limbah Cair untuk perusahaan tersebut, namun seharusnya setiap usaha maupun pabrik tersebut sudah mempunyai izin masing-masing akan tetapi implementasinya sangat belum optimal diterapkan kepada para pemilik usaha maupun perusahaan. ${ }^{4}$ Namun pada prakteknya bahwa limbah yang dibuang ke laut oleh pabrik sudah tecemar namun izin yang dibuat oleh pabrik tersebut masih dalam proses. Tetapi secara peraturan bahwa kegiatan dan/atau usaha harus memiliki izin terlebih dahulu yang diumumkan oleh Pemerintah. Setelah keluarnya izin tersebut, maka kegiatan dan/atau usaha diperbolehkan sebagaimana mestinya. Pengawasan terkait izin limbah pabrik tersebut merupakan suatu kajian yang baru dalam perkembangan hukum lingkungan, sehingga kewajiban melindungi sumber daya lingkungan dapat dimasukan kedalam ketentuan - ketentuan perizinan limbah pabrik, baik dalam tatanan penyajian permohonan dan pernyataan serta sesudah

${ }^{3}$ Undang-Undang Nomor 32 Tahun 2009 Tentang Perlindungan dan Pengelolaan Lingkungan Hidup, Pasal 1 Angka 35.

4 Hardjasoemantri, Koesnadi. Hukum Tata Lingkungan Edisi VIII, (Yogyakarta, Gadjah Mada University Press, 2012) , h. 329. 
mendapatkan izin usaha dalam implementasi penanggulangan pencemaran lingkungan. Sebagai contoh di Desa Pengambengan, Kecamatan Negara, Jembrana terdapat Pabrik Tepung Ikan yakni PT. Bumi Bali Mina yang membuang limbah pabrik ke laut sebelum keluarnya izin dari Pemerintah Daerah, hal tersebut secara prosedur dan aturan tidak di perbolehkan.

Adapun alasan mengapa penulis tertarik dalam pemilihan judul diatas untuk digunakannya bahan penelitian disebabkan belum adanya penelitian yang terdahulu mengkaji dan menganalisis mengenai Pengaturan Izin Pembuangan Limbah Pabrik Ke Laut di Kabupaten Jembrana. Sehingga, penulis mempunyai alasan yang kuat dalam mengangkat judul tersebut. Disamping itu, penulis berupaya untuk mengkaji persoalan yang ada terkait izin pembuangan limbah pabrik ke laut sebelum ada izin agar pabrik - pabrik yang terdapat di Kabupaten Jembrana bisa mengikuti prosedur - prosedur yang telah di atur oleh Pemerintah Daerah.

\subsection{Rumusan Masalah}

Berlandaskan pemaparan latar belakang diatas, bahwa penulis sangat tertarik untuk mengkaji rumusan masalah yakni :

1. Bagaimana pengaturan terkait pembuangan limbah Pabrik ke laut sebelum ada izin?

2. Bagaimana pengawasan pemerintah Kabupaten Jembrana terhadap pabrik yang membuang limbah ke laut tanpa izin?

\subsection{Tujuan Penulisan}

1. Untuk mengetahui pengaturan terkait pembuangan limbah pabrik ke laut sebelum adanya izin yang diterbitkan oleh Pemerintah Daerah.

2. Untuk mengetahui dalam pengawasan pemerintah Kabupaten Jembrana terhadap Pabrik yang membuang limbah ke laut sebelum adanya izin dari Pemerintah Daerah.

\section{Metode Penelitian}

Penelitian ini mengaplikasikan penelitian hukum normatif. Penelitian penelitian seperti itu adalah penelitian yang menitik bebankan kepribadian individu maupun penduduk serta warga yang intens hubungannya dengan hukum. Penelitian ini meneliti hukum pada sudut pandang eksternal dengan sasaran penelitiannya merupakan sikap dan kepribadian sosial kepada hukum. Metode hukum normative adalah metode yang mengkaji suatu aturan hukum pada aspek dan sudut pandang didalamnya yang objek pengkajiannya adalah norma hukum. ${ }^{5}$ Beberapa objek yang sering dimanfaatkan dalam penelitian normatif yakni masalah penerapan aturan hukum, kedudukan institusi penegak hukum dalam penegakkan hukum dan tidak

5 Pasek Diantha, I Made. Metode Penelitian Normatif Dalam Justifikasi Teori Hukum, (Jakarta, Prenada Media Group, 2016), h. 12. 
lupa masalah efektifitas aturan hukum. Adapun yang luas pada penelitian ini yakni terkait pembuangan limbah pabrik ke laut yang belum ada izinnya.

\section{Hasil dan Pembahasan}

\subsection{Pengaturan Pembuangan Limbah Pabrik Ke Laut di Kabupaten Jembrana}

Hukum lingkungan berlandaskan segala perspektif lingkungan semacam saran yang menjadi jangkauannya. Hukum lingkungan mempunyai ruang lingkup yang sama besar berkaitan dengan segala kawasan sumber daya alam lingkungan, baik yang dalam bagian fisik, atau sosial, dan juga yang tergolong baik dalam beragam tingkatan secara alamiah, atau secara administratif sektoral, adalah komponen menyeluruh dari lingkungan. ${ }^{6}$

Kompensasi terhadap lingkungan dan kesehatan yang menyebabkan berdampak terhadap kontaminasi dan destruksi lingkungan mampu berkelakuan tidak tersembuhkan (irreversible). Oleh karena itu, pengelolaan lingkungan seharusnya makin dilandasi dalam usaha preventif dari pada pengembalian. Hukum lingkungan administrasi mempunyai peranan dalam upaya pencegahan dan peran korektif terhadap aktivitas - aktivitas yang tidak mentaati aturan atau prasyarat yang telah ditentukan dalam pengelolaan lingkungan. Peranan terkait dalam pencegahan terhadap munculnya persoalan - persoalan lingkungan yang bermula dari suatu aktivitas usaha yang dibentuk dalam wujud pemeliharaan yang dilaksanakan kepada oknum yang berkedaulatan di bagian pemeliharaan lingkungan. Pengawasan lingkungan hidup yang kemudian disebut pengawasan yakni hubungan aktivitas yang dilakukan pada Pejabat Pengawas Lingkungan Hidup dan/atau Pejabat Pengawas Lingkungan Hidup Daerah untuk memahami, menegaskan, dan memutuskan jenjang kedisiplinan penanggungjawab usaha dan/atau aktivitas berdasarkan aturan yang diputuskan dalam izin lingkungan dan peraturan perundang - undangan diranah perlindungan dan pengelolaan lingkungan hidup. Pengawasan lingkungan hidup adalah aktivitas yang dilakukan secara spontan atau tidak spontan oleh Pegawai Negeri yang memperoleh surat tugas bertujuan melaksanakan pengawasan lingkungan hidup atau Pejabat Pengawas Lingkungan Hidup (PPLH) di pusat atau daerah. Aktivitas tersebut dimaksud untuk mengontrol dan memahami tingkat kedisiplinan penanggungjawab aktivitas tersebut dan/atau usaha terhadap peraturan perundang - undangan yang berhubungan dengan persoalan lingkungan hidup yang tergolong didalamnya pengawasan terhadap kedisiplinan yang ditertibkan terkait pada perizinan ataupun pada dokumen Analisis Mengenai Dampak Lingkungan (AMDAL) atau Upaya Pengelolaan Lingkungan (UKL) dan Upaya Pemantauan Lingkungan (UPL).

Implementasi kaitannya pada penanggulangan pengaruh terhadap lingkungan hidup dilaksanakan beserta dilandaskan dengan perancangan perlindungan dan

${ }^{6}$ Saraswati, R., Wiharmoko, A. A., \& Hardjanto, U. S.. Pengelolaan Limbah di PT Phapros Semarang Berdasarkan Undang-undang Nomor 32 Tahun 2009 Tentang. Diponegoro Law Review, (2012), 1(4). 
pengelolaan lingkungan hidup yang menyeluruh inventarisasi lingkungan hidup, dalam ketetapan wilayah ekoregian, dan RPPLH (Rencana Perlindungan dan Pengelolaan Lingkungan Hidup) pasal 5 Undang - Undang No. 3 Tahun 2009 Tentang Perlindungan dan Pengelolaan Lingkungan Hidup, yang harus ditertibkan hingga makin spesifik didalam peraturan pemerintah (PP) dan Peraturan Daerah (Perda) bertujuan dalam memastikan kegiatan dalam penerapannya. Wilayah ekoregion memiliki kedudukan yang strategis karena semua pengendalian pengaruh lingkungan hidup, berhubungan terhadap izin lingkungan yang dikeluarkan oleh pejabat yang berkedaulatan dibagian lingkungan hidup, sehingga dilandaskan terhadap daya dukung dan daya tampung lingkungan hidup disebuah wilayah ekoregion searah dengan pendataan lingkungan hidup diwilayah ekoregion tersebut. Pengendalian pengaruh lingkungan hidup melingkupi 3 (tiga) bagian penting, diantaranya : Pencegahan, penanggulangan dan pemulihan yakni diatur dalam pasal 13 UU. 32 Tahun 2009 tentang PPLH. Antara lain ketiga bagian penanggulangan tersebut, pencegahan pengaruh lingkungan hidup memperoleh bagian penyelarasan yang sangat berlimpah, yakni salah satunya terkait dengan pencemaran limbah tepung ikan.

Limbah dan sampah berkemampuan tinggi terkait pada terkontaminasinya lingkungan lantaran menimbulkan merosotnya karakteristik lingkungan hidup dan mengganggu ekosistem naturalisasi. Pengaruh negatif dari merosotnya karakteristik lingkungan hidup, baik lantaran penyebabnya terkontaminasi maupun kecacatannya sumber daya alam merupakan tampaknya intimidasi maupun pengaruh negatif kepada kestabilan, merosotnya kualitas estetika, kerugian ekonomi (economic cost), dan terhambatnya sistem alami (natural system).

Penjelasan terkait dengan izin berdasarkan definisi yakni menyetujui maupun pengesahan yang di perbolehkan. Sebaliknya, terminologi mengizinkan memiliki makna menyetujui, mengabulkan, tidak mengekang. ${ }^{7}$ Menurut pandangan sjachran Basah, izin merupakan perbuatan hukum secara administrasi yang berdaulat beraspek satu yang terkait implementasinya pada ketentuan terhadap suatu objek yang substansial berlandaskan prasyarat maupun proses sebagaimana yang dipersetujukan kepada ketetapan kebijakan konstitusi perundangan. Izin tidak berkenan melaksanakan entitas melainkan diizinkan. Maka, kegiatan kepada suatu sasaran tertentu dalam latar belakangnya tidak diperbolehlan. Seseorang maupun organ aturan - aturan bisa melaksanakan usaha maupun akivitas atas suatu objek tersebut bila memperoleh izin dari pemerintah/pemerintah daerah yang menumbuhkan fungsinya kepada aktivitas yang dilaksanakan oleh orang atau golongan yang berhubungan. Dengan terkontaminasinya lingkungan hidup pada limbah dan sampah karakter estetika tersebut hendak merosot, lingkungan yang terkontaminasi tersebut hendak timbul keruh dan tidak berkenan dipergunakan untuk keperluan sehari - hari. Terkontaminasinya lingkungan pula akan memprovokasi struktur alamiah melalui lingkungan tersebut, elemen yang ditemukan oleh lingkungan akan berpotensi hancur dan tercemar. ${ }^{8}$ Peraturan Pemerintah akhirnya meningkat terkait pada beberapa

${ }^{7}$ http://wonkdermayu.wordpress.com/kuliah-hukum/hukum-perijinan/. Diakses pada hari Sabtu, 19 Oktober 2019 jam 22.34 WITA.

8 Permadi, I. M. A., \& Murni, R. R. Dampak Pencemaran Lingkungan Akibat Limbah Dan Upaya Penanggulangannya Di Kota Denpasar. Kertha Negara, (2013), 1(06). Retrievedfrom https://ojs.unud.ac.id/index.php/Kerthanegara/article/view/6411 
ketentuan yang mengatur menyinggung tentang kontaminasi dan maupun kerusakan lingkungan yang terkait pada artikel ini yang berhubungan tentang pembuangan (dumping) limbah tanpa izin. Degan pembuangan limbah tanpa pengelolaan terlebih dahulu, sehingga hal tersebut akan memperoleh pengaruh negatif oleh lingkungan. ${ }^{9}$ Kondisi ini tergambar dalam Pasal 20 Ayat (3)UU No. 32 Tahun 2009 Tentang UU No. 32 Tahun 2009 Tentang PPLH, yang dijelaskan :
"Setiap orang diperbolehkan untuk membuang limbah ke media lingkunganhidupdengan persyaratan :
a) Mematuhi baku mutu lingkungan hidup, dan
b) Memperoleh izin dari Menteri, Gubernur, atau Bupati/Walikota sesuai dengan kewenangannya".

Pada Pasal 60 UU. No. 32 Tahun 2009 Tentang PPLH pula dijelaskan bahwa "Setiap orang dilarang melakukan dumping limbah dan/atau bahan ke instrumen lingkungan hidup tanpa izin", maka sangat jelas bahwa disini seseorang melaksanakan kegiatan membuang limbah wajib bersama dengan izin. Izin tersebut akan keluar bila masyarakat/penduduk yang bermaksud melaksanakann pembuangan limbah ke instrumen lingkungan yang dalam hal ini membuang limbah pabrik tepung ikan ke laut telah mentaati ketentuan - ketentuan yang wajib didapatkan bertujuan memperoleh sebuah izin. Atas aktivitas pembuangan limbah tepung ikan tersebut ke media lingkungan yang dalam hal ini ke laut tanpa izin oleh PT. Bumi Bali Mina, dimana pabrik tersebut membuang limbah tepung ikan ke laut yang belum ada izin, sehingga Pasal 104 UU No. 32 Tahun 2009 Tentang PPLH terkait pada sanksi pemidanaannya yang dijelaskan bahwa :

"Setiap orang yang melaksanakan dumping limbah dan/atau bahan ke instrumen lingkungan hidup tanpa izin sebagaimana dijelaskan dalam pasal 60, dipidana dengan pidana penjara palinglama 3 (tiga) tahun dan denda paling banyak $R p$. 3000.000.000,00,- (tiga miliar rupiah)".

Sehingga tujuan suatu pencegahan perbuatan pembuangan limbah tersebut, yakni dalam Pasal 238 Peraturan Pemerintah Nomor 101 Tahun 2014 menggolongkan terkait pada pemantauan pada setiap orang yang memperoleh, mengumpulkan, mengangkut, memanfaatkan, mengarahkan, dan/atau menimbun limbah B3 dan setiap orang yang melakukan dumping (pembuangan) limbah B3. Pengawasan dilaksanakan oleh Menteri, Gubernur dan/atau Bupati/Walikota dengan menentukan pejabat fungsional Pejabat Pengawas Lingkungan Hidup (PPLH). Pemantauan dilaksanakan dengan sistem verifikasi informasi dalam pengelolaan limbah B3 dan/atau pembuangan limbah B3 juga melaksanakan peninjauan. Fungsi dilakukannya pemantauan bertujuan untuk memverifikasi keabsahan informasi tentang sistem tata cara pengelolaan limbah dan pembuangan limbah tersebut sebanding kepada yang berlangsung dilapangan.

${ }^{9}$ Soemantri, Y. V., Sularto, R. B., \& Wisaksono, B. Lingkungan Hidup (Studi Dumping Limbah tanpa Izin Terkait dan Berdasarkan Putusan Nomor 61/pid. sus/2015/pn. unr. Jo. Nomor 162/pid. sus/2016/pt. smg.). Diponegoro Law Journal, (2017) 6(2), 1-18. 
Namun terkait kepada pemecahan perselisihan lingkungan hidup dengan melaksanakan strategi ancangan perangkat hukum administrasi lingkungan pula berpedoman dalam beberapa kebijakan peraturan - peraturan yang menyangkut dengan persoalan lingkungan hidup. Pengingkaran yang dilakukan oleh pabrik tepung ikan PT. Bumi Bali Mina tersebut yang belum ada izin pembuangan limbah pemecahan persoalan tersebut dilaksanakan terlebih dahulu dengan musyawarah. Tetapi, jika tidak terselesaikan dengan sistem musyawarah sehingga diarahkan ke proses pengadilan. Kerap jika terdapat pengingkaran berhubungan dengan tidak mempunyai izin membuang limbah tepung ikan tersebut bahwa akan memperoleh sanksi administrasi. Apabila sanksi yang bertindak untuk pengingkaran yang tidak mempunyai izin pembuangan limbah cair yang dalam hal ini limbah tepung ikan maka memperoleh surat teguran. Pada fakta yang terjadi pemantauan yang dilaksanakan serta penegakan hukum kepada pembuangan limbah tepung ikan tanpa izin yang dilaksanakan oleh pabrik tepung ikn PT. Bumi Bali Mina belum efisien. Adapun pengawasan yang dilaksanakan belum bersifat optimal dikarenakan jumlah Satuan Polisi Pamong Praja (SATPOL PP) serta lembaga - lembaga yang berhubungan dengan jumlah yang masih relatif terbatas. Kemudian sanksi yang diperoleh hingga saat ini sekedar sebatas dengan peringatan ketika dilaksanakannya peninjauan kepada petugas satpol pp serta instansi yang lainnya. Sanksi yang diperoleh pun hanya bersifat peringatan oleh satpol pp serta dinas lingkungan hidup kabupaten jembrana maka tidak mempunyai rasa takut atau efek jera terhadap tindakan usaha pabrik tepung ikan apakah sudah memiliki izin atau tidak namun sangat disayangkan, karena untuk membentuk pabrik teping ikan, pelaku usaha pabrik tersebut diwajibkan mempunyai izin limbah, sedangkan pengawasan yang dilaksanakan oleh dinas lingkungan hidup merupakan pengawasan terhadap pelaku usaha pabrik tepung ikan yang dilaksanakan secara teratur selama 6 bulan sekali apakah pelaku pabrik tepung ikan melaksanakan pengingkaran. Adapun norma yang terkandung dalam penulisan journal ini yakni konflik norma, dimana tindakan dari Pabrik tersebut menyalahi aturan sebagaimana pabrik tersebut membuang limbah ke laut namun izin limbah tersebut belum keluar, alasannya bahwa izin limbah pabrik tersebut sedang diproses oleh Dinas Lingkungan Hidup Kabupaten Jembrana, dan dari segi aturan tidak diperbolehkan oleh Peraturan Daerah. Teori yang relevan digunakan yakni Penegakan Hukum terkait pelanggaran Izin Pembuangan Limbah Pabrik Ke Laut yang belum keluar di Kabupaten Jembrana yang secara preventif dilaksanakan berdasarkan prosedur - prosedur tertentu dalam wujud pembuatan izin Limbah. Ketentuan sanksi administratif yang berdasarkan Peraturan Daerah Kabupaten Jembrana Nomor 5 Tahun 2007 Tentang Kebersihan dan Ketertiban Umum di Kabupaten Jembrana.

\subsection{Pengawasan Pemerintah Kabupaten Jembrana Terhadap Pabrik yang membuang Limbah Ke Laut Tanpa Izin}

Pengelolaan lingkungan hidup dilakukan menggunakan landasan pertanggungjawaban negara, asas berkesinambungan, dan asas keistimewaan bermaksud bertujuan membentuk pengembangan berkesinambungan yang memahami lingkungan hidup terkait dengan rencana pengembangan masyarakat indonesia yang integral serta pengembangan penduduk indonesia secara keseluruhan. Sebagai dampak dari adanya tanggungjawab negara terkait pada pengelolaan 
lingkungan hidup, sehingga negara memiliki peran dan kewajiban menciptakan perancangan, perlindungan, pembaharuan dan pemantauan, dan juga peran dengan kewajiban lainnya. ${ }^{10}$ Dengan adanya peran tersebut menyebabkan dampak tertentu yakni didapatkannya suatu tugas yang wajib dilakukan masyarakat terkait serta dengan kedudukan maupun kapasitasnya. Akan tetapi bila kedudukan dikaitkan beserta kedaulatan terkait pada membereskan kontaminasi limbah yang dihasilkan oleh pabrik tepung ikan adalah kedudukan terkait pada kewajiban maupun tugas yang semestinya kedaulatan laksanakan beserta membereskan pencemaran limbah yang disebabkan oleh pabrik tepung ikan agar dapat berupaya mengecilkan suatu kualitas pencemaran yang ada. Kedaulatan kaitannya terhadap hal tersebut ialah Pemerintah Pusat dan Pemerintah Daerah. Pemerintah Pusat yakni Presiden Republik Indonesia yang menduduki kedaulatan pemerintahan Negara Republik Indonesia sebagaimana sudah dijelaskan berdasarkan Undang - Undang Dasar Negara Republik Indonesia Tahun 1945, dan juga beberapa Menteri dan Pimpinan Lembaga Pemerintahan Non Departemen. Pemerintah Daerah terkait pada Undang-Undang No. 32 Tahun 2004 tentang Pemerintahan Daerah dijelskan yakni Pemerintah Daerah adalah Gubernur, Walikota, Bupati dan perangkat daerah sebagai bagian pelaksana pemerintah daerah. Pemerintah mengklasifikasikan serta mengerjakan secara individu masalah pemerintahan berdasarkan asas otonomi dan kewajiban pendampingan.

Dalam mekanisme substansi terkait dengan kedudukan kunci stake holders (Pemangku Kepentingan), melingkupi 3 (tiga) ranah Good Governance, yakni pemerintah, swasta dan masyarakat. Kaitannya atas adanya kedudukan pemerintah terkait pada membereskan kontaminasinya limbah industri pabrik tepung ikan terhadap PT. Bumi Bali Mina di Kabupaten Jembrana berorientasi terkait dengan asas asas serta bagian utama governance yang bisa membangun Good Environmental Governance.

Good Environmental Governance merupakan lembaga kedaulatan yang mengendalikan lingkungan dengan baik. Penyebab internal yang dimanfaatkan bertujuan mempertimbangkan serta memperhitungkan persediaan, kegunaan, perancangan, penerapan serta kapasitas ekonomi dengan baik. Good Environmental Governance meliputi Kelembagaan Kedaulatan yang mengendalikan lingkungan secara baik serta mencermati asas - asas pengembangan yang berkesinambungan. ${ }^{11}$

Pengawasan izin lingkungan di Kabupaten Jembrana diupayakan dengan Badan lingkungan Hidup berharmonisasi terhadap Pemerintah Daerah Provinsi Bali melewati Badan Pelayanan Perizinan Terpadu Provinsi Bali sebagai peroleh izin usaha ataupun izin lingkungan.

Pemakaian izin selaku perangkat pengawasan ditentukan dengan diberikannya izin - izin tertentu kepada kegiatan masyarakat. Beragam prosedur terkait pada penyelenggara izin adalah pengaturan pada mengfungsikan izin tersebut menjadi

${ }^{10}$ Subhi, M. Perizinan Pembuangan Limbah Cair Kegiatan Industri Dalam Hubungannya Dengan Pengendalian Pencemaran Air (Studi Di Kabupaten Ketapang). Jurnal NESTOR Magister Hukum, (2013), 2(2).

${ }^{11}$ Maghfiro, I. Analisis Peran Pemerintah dalam Mengatasi Limbah Industri Pabrik Gula Tjoekir (Studi pada Badan Lingkungan Hidup Kabupaten Jombang). Jurnal Administrasi Publik, (2013), 1(3), 94-102. 
instrumen bertujuan pemantauan kegiatan penduduk, serta kegiatan yang di tagihi izin ialah kegiatan yang membutuhkan pemantauan secara eksklusif, serta terkait diberikannya izin pembuangan limbah ke laut terkait pabrik tepung ikan ditentukannya beberapa prosedur yang wajib dilengkapi oleh penagihan izin. Dalam pemantauan diperlukan sebagai perlindungan hukum untuk warga negara terhadap akibat dari publikasi dalam ketentuan - ketentuan tata usaha negara. ${ }^{12}$ Pemerintah melaksanakan pemerintahan melewati jangkauan ketentuan pemerintahan yang berkarakter penting, kebijakan atau ketetapan - ketetapan umum melewati langkah langkah pemerintahan yang berkarakter memberdirikan keharmonisasian secara global. Keputusan administrasi negara yang berbentuk pemutusan dijelaskan pula langkah - langkah administrasi negara dalam melaksanakan kewajiban di bagian publik service, memerlukan kewenangan berdasarkan hukum publik, terkait hal ini hukum administrasi negara.

Peranan pemantauan terkait halnya kepada izin yang sudah dimunculkan secara absolut dibutuhkan bertujuan menyelinapi kekeliruan - kekeliruan terkait dengan izin yang sudah dimunculkan sehingga tidak di salah gunakan. Pemantauan terkait dengan izin tersebut merupakan tanggungjawab instansi - instansi yang mengeluarkan izin tersebut. Untuk melakukan suatu upaya preventif dan mengatasi limbah industri yang disebabkan oleh pabrik tepung ikan maupun mencegah industri yang belum memiliki izin, maka pemerintah patut bertindak dinamis baik melewati perundang undangan ataupun dengan pelaksanaan yang lain. Pemerintah patut menekunkan pengembangan yang berkepanjangan yakni Sustainable Development terhadap pemahaman yang pengetahuan ke depan dengan harapan sehingga bisa dipergunakan bagi angkatan sekarang ataupun angkatan yang akan datang. UU No. 32 Thun 2009 tentang PPLH pasal 3 huruf (a) menjelaskan bahwa, Perlindungan dan pengelolaan lingkungan hidup berfungsi melindungi wilayah Negara Kesatuan Republik Indonesia dari pencemaran dan/atau kerusakan lingkungan hidup. Dalam petikan UU No. 32 Tahun 2009 tentang PPLH dijelaskan bahwa, ketentuan ini mempersembahkan kekuasaan terhadap pemerintah untuk mengurangi tindakan - tindakan tertentu seperti contoh di bidang perpajakkan sebagai dorongan berfungsi lebih untuk menumbuhkan pemeliharaan lingkungan dan dis-insentif untuk melakukan upaya preventif pada perusakan dan pencemaran lingkungan.

Izin (vergunning dari pemerintah ) menurut undang - undang atau peraturan perundang - undangan atau juga peraturan pemerintah yang di indikasi untuk suatu tindakan yang pada umumnya membutuhkan pemantauan eksklusif, tetapi yang pada umumnya tidak diduga sebagai suatu hal yang sama sekali tidak dimaksudkan. Kekuasan pemerintah dalam bidang izin dapat dijelaskan pemerintah diperoleh kekuasaan untuk membandingkan berlandaskan secara individu faktor - faktor yang menyangkut dengan izin, seperti contoh perimbangan terkait keadaan - keadaan yang berpotensi suatu izin bisa diberikan kepada pemohon atau si pembutuh izin. Pengaruh yuridis yang barangkali yang kelihatan akibat pemberi izin. Dan juga ketentuan yang mesti diikut sertakan atau dibereskan pada saat dan setelah keputusan diberikan. Perizinan semata - mata bisa dikeluarkan bila ditemukan Analisis Mengenai Dampak Lingkungan (AMDAL), dan Upaya Pemantauan Lingkungan Hidup (UKL) dan Upaya

${ }^{12}$ Hakim, M. Z. Izin Sebagai Instrumen Pengawasan dalam Mewujudkan Pemerintahan yang Baik. Jurnal Hukum Islah, (2017), 13(29). 
Pemantauan Lingkungan Hidup (UPL). Izin lingkungan diperoleh dalam kepastian hukum kepada industri pabrik tepung ikan di kabupaten jembrana bahwa usaha mereka sudah memenuhi semua prosedur dibidang lingkungan hidup. Tetapi dalam kenyataannya pabrik tepung ikan tersebut belum ada izinnya dalam pembuangan limbah ke laut. Pemerintah seharusnya bersikap tegas dalam menanggulangi kegiatan yang belum ada izinnya. Izin lingkungan tersebut diberlakukan karena kehendak untuk mengendalikan pemanfaatan sumber daya alam, mengendalikan pencemaran dan/atau kerusakan lingkungan hidup, dan memberikan kepastian hukum untuk melakukan kegiatan dan/atau usaha.

Berbagai usaha dalam suatu aktivitas yang dilaksanakan oleh penduduk di kabupaten Jembrana diatur oleh Pemerintah Daerah, yakni salah satunya yang sangat diatur kepada Pemerintah Daerah Kabupaten Jembrana yakni berhubungan kepada pemeberian izin dalam suatu aktivitas maupun kegiatan usaha yang dilaksanakan oleh penduduk setempat di Kabupaten Jembrana. Pelaksanaan perizinan di wilayah Kabupaten Jembrana di samping berfungsi untuk diperolehkan suatu legalitas atas operasional aktivitas tersebut yang dilaksanakan oleh penduduk setempat, memiliki kapasitas lebih utama sebagai media penanggulangan Pemerintah Daerah atas operasional kegiatan sehingga kegiatan yang dilaksanakan oleh masyarakat bisa memberikan kegunaan untuk pemilik kegiatan, tidak memprovokasi kebutuhan penduduk yang lainnya serta dapat mengalokasikan kepentingan untuk penduduk pada dasarnya.

Dalam implementasi pengawasan di lapangan tentu saja kantor Dinas Penanaman Modal dan Pelayanan Izin Terpadu Kabupaten Jembrana tidak melaksanakannya secara langsung, hanya saja dalam pengawasan kepada izin yang belum ada terkait pembuangan limbah tepung ke laut didukung oleh satuan polisi pamong praja yang melaksanakan sidak-sidak ke tempat usaha tersebut serta melakukan pemeriksaan terkait kelengkapan dokumen perizinan, dan terbukti dalam operasi sidak yang dilaksanakan ke tempat usaha tersebut tidak mempunyai dokumen perizinan sehingga satuan polisi pamong praja tersebut secara langsung memberikan tindakan berupa pemberian surat peringatan dan menyuruh pelaku usaha tersebut menutup sementara usaha pabrik tepung ikan tersebut sampai dokumen yang dibutuhkan dalam kegiatan usahanya lengkap, serta dari satuan polisi pamong praja tersebut dengan cepat menyampaikan kepada dinas terkait bawasannya pada dasarnya usaha yang terkena sidak tersebut tidak mempunyai dokumen kegiatan/usaha yang lengkap.

Peran dan kewenangan pemerintah Kabupaten Jembrana terkait dengan kedudukan yang sudah dimiliki oleh Dinas lingkungan Hidup Kabupaten Jembrana bahwa kedudukan yang dimiliki oleh Dinas Lingkungan dan Pengelolaan Hidup yakni menerbitkan dokumen lingkungan tersebut akan dilaksanakannya tugas utama yakni pemantauan, pemantauan yang dilaksanakan sangat luas sehubungan dengan penyerahan yang dilaksanakan oleh kegiatan usaha yang memohon penerbitan lingkungan. Sebelum menyerahkan permohonan penerbitan dokumen lingkungan pelaku usaha harus mempunyai dokumen izin pemanfaatan laut atau yang secara rasional disebut dengan izin prinsip, bila sudah mempunyai izin prinsip maka pelaku usaha bisa langsung menyerahkan permohonan penerbitan izin lingkungan ke Dinas Lingkungan Hidup, tentunya melakukan suatu upaya pengkajian kembali kepada izin prinsip yang sudah ada. Berkaitan dengan kegiatan usaha yang melanggar atau tidak 
menjalankan usaha sesuai dengan yang diperintahkan dalam dokumen lingkungan tersebut maka Dinas Lingkungan Hidup akan melaksanakan peninjauan kembali dan apabila terbukti melaksanakan kesalahan yang tidak sesuai dengan peraturan yang ada dalam dokumen lingkungan maka akan diterbitkan surat peringatan pertama dan bila usaha tersebut masih tidak melakukan pembenahan dan masih tidak melaksanakan yang diperintahkan dalam dokumen lingkungan tersebut maka akan diberikan surat peringatan kedua dan juga dapat dilaksanakannya pencabutan dokumen lingkungan tersebut.

Penerbitan izin lingkungan juga tidak dapat dilakukan dengan cepat karena dalam melaksanakan penerbitan dokumen lingkungan harus dilakukan pengkajian kepada kondisi lingkungan dikawasan sekitar usaha kegiatan tersebut yang sedang mengajukan permohonan terkait dengan dokumen lingkungan, harus diumumkan terlebih dahulu dan pihak pemohon harus memaparkan kegiatan usahanya tersebut di hadapan dinas - dinas berkaitan untuk memberikan gambaran tentang kegiatan usahanya.

\section{Kesimpulan}

Pengawasan izin lingkungan di Kabupaten Jembrana diupayakan dengan Badan lingkungan Hidup berharmonisasi terhadap Pemerintah Daerah Provinsi Bali melewati Badan Pelayanan Perizinan Terpadu Provinsi Bali sebagai peroleh izin usaha ataupun izin lingkungan. Pemakaian izin selaku perangkat pengawasan ditentukan dengan diberikannya izin - izin tertentu kepada kegiatan masyarakat. Beragam prosedur terkait pada penyelenggara izin adalah pengaturan pada mengfungsikan izin tersebut menjadi instrumen bertujuan pemantauan kegiatan penduduk, serta kegiatan yang di tagihi izin ialah kegiatan yang membutuhkan pemantauan secara eksklusif, serta terkait diberikannya izin pembuangan limbah ke laut terkait pabrik tepung ikan ditentukannya beberapa prosedur yang wajib dilengkapi oleh penagihan izin. Keputusan administrasi negara yang berbentuk pemutusan dijelaskan pula langkah langkah administrasi negara dalam melaksanakan kewajiban di bagian publik service, memerlukan kewenangan berdasarkan hukum publik, terkait hal ini hukum administrasi negara.

Peran dan kewenangan pemerintah Kabupaten Jembrana terkait dengan kedudukan yang sudah dimiliki oleh Dinas lingkungan Hidup Kabupaten Jembrana merupakan kedudukan yang dimiliki oleh Dinas Lingkungan Hidup yakni menerbitkan dokumen lingkungan tersebut akan dilaksanakannya tugas utama yakni pemantauan, pemantauan yang dilaksanakan sangat luas sehubungan dengan penyampaian yang dilaksanakan oleh aktivitas suatu usaha yang memohon penerbitan lingkungan. Sebelum menyerahkan permohonan penerbitan dokumen lingkungan pelaku usaha harus mempunyai dokumen izin pemanfaatan laut atau yang secara rasional disebut dengan izin prinsip, bila sudah mempunyai izin prinsip maka pelaku usaha bisa langsung menyerahkan permohonan penerbitan izin lingkungan ke Dinas Lingkungan Hidup, tentunya melakukan suatu upaya pengkajian kembali kepada izin prinsip yang sudah ada. 


\section{Daftar Pustaka}

\section{Buku}

Diantha, Made Pasek. Metodelogi Penelitian Hukum Normatif Dalam Justifikasi Teori Hukum, (Jakarta, Kencana, 2016).

Hardjasoemantri, Koesnadi. Hukum Tata Lingkungan Edisi VIII, (Yogyakarta, Gadjah Mada University Press, 2012).

Siahaan, N.H.T. Hukum Lingkungan, (Jakarta, Pancuran Alam, 2009).

\section{Jurnal}

Panata, Y.Penurunan Status Kawasan Cagar Alam Menjadi Taman Wisata Alam Di Kabupaten Garut Dihubungkan Dengan Undang-Undang No 5 Tahun 1990 Tentang Konservasi Sumber Daya Alam Hayati Dan Ekosistemnya Jo Undang-Undang No 32 Tahun 2009 Tentang Perlindungan Dan Pengelolaan Lingkungan Hidup ( Fakultas Hukum Universitas Pasundan, Doctoral dissertation, 2019).

Saraswati, R., Wiharmoko, A. A., \& Hardjanto, U. S. Pengelolaan Limbah di PT Phapros Semarang Berdasarkan Undang-undang Nomor 32 Tahun 2009 Tentang. Diponegoro Law Review, (2012), 1(4).

Permadi, I. M. A., \& Murni, R. R. Dampak Pencemaran Lingkungan Akibat Limbah Dan Upaya Penanggulangannya Di Kota Denpasar. Kertha Negara, (2013), 1(06). Retrievedfrom https://ojs.unud.ac.id/index.php/Kerthanegara/article/view/6411

Soemantri, Y. V., Sularto, R. B., \& Wisaksono, B. Lingkungan Hidup (Studi Dumping Limbah tanpa Izin Terkait dan Berdasarkan Putusan Nomor 61/pid. sus/2015/pn. unr. Jo. Nomor 162/pid. sus/2016/pt. smg.). Diponegoro Law Journal, (2017), 6(2).

Subhi, M. Perizinan Pembuangan Limbah Cair Kegiatan Industri Dalam Hubungannya Dengan Pengendalian Pencemaran Air (Studi Di Kabupaten Ketapang). Jurnal NESTOR Magister Hukum, (2013), 2(2).

Maghfiro, I. Analisis Peran Pemerintah dalam Mengatasi Limbah Industri Pabrik Gula Tjoekir (Studi pada Badan Lingkungan Hidup Kabupaten Jombang). Jurnal Administrasi Publik, (2013), 1(3).

Hakim, M. Z. Izin Sebagai Instrumen Pengawasan dalam Mewujudkan Pemerintahan yang Baik. Jurnal Hukum Islah, (2017), 13(29).

\section{Web}

HYPERLINK "http://wonkdermayu.wordpress.com/kuliah-hukum/hukumperijinan/" http://wonkdermayu.wordpress.com/kuliah-hukum/hukumperijinan/ . Diakses pada hari Sabtu, 19 Oktober 2019 jam 22.34 WITA.

\section{Undang - Undang}

Undang-Undang Nomor 32 Tahun 2009 Tentang Perlindungan dan Pengelolaan LingkunganHidup, Pasal 1 Angka 35. 